\title{
Gender Dynamics Determining Men and Women's involvement in Community Conflicts through Alternative Dispute Resolution (ADR) Mechanisms in Kapsokwony, Kenya
}

\author{
Benson Muthama Prof. Grace Ngare Dr. Leah Wanjama \\ School of Humanities and Social Sciences, Department of Sociology, Gender and Development Studies, \\ Kenyatta University, P.O Box: 43844-00100 Nairobi, Kenya
}

\begin{abstract}
This article outlines the gender dynamics that determine men and women's involvement in Alternative Dispute Resolution (ADR) Mechanisms in Kapsokwony, Bungoma County. It highlights that while ADR mechanisms are normally considered participatory and inclusive in Kenya, the reality however is that they remain male dominated. The study was based on a mixed research method whose methodology involved research survey, interview, and Focus Group Discussions. Findings from studies carried out across the global confirm that men continue to have upper hand over women with regards to participation in conflict resolution using ADR (Alternative Dispute Resolution) mechanisms for number of reasons. The situation was found not different in the context of Kapsokwony, a sub-county of Bungoma County in Kenya. This study discussed the multidimensional factors that continue to contribute to men upper hand over women in resolving conflict through ADR mechanisms.
\end{abstract}

Keywords: Gender equality, Participation, Exclusion, Alternative Dispute Resolution, conflict Resolution DOI: $10.7176 /$ RHSS/10-21-05

Publication date: November $30^{\text {th }} 2020$

\section{Introduction}

The Constitution of Kenya, 2010 recognizes the application of ADR mechanisms in dispute resolution for efficient dispensation of justice. It establishes a strong elaborate human rights framework embodying the fundamental rights and freedoms entitled to the citizens. To achieve this, the Constitution dedicates an entire Chapter Four to human rights, which embodies the Bill of Rights (Muigai, 2017). Its Article 159 stipulates that in the exercise of the judicial authority, courts and tribunals are to promote alternative forms of dispute resolutions including reconciliation, mediation, arbitration, and traditional dispute resolution mechanisms.

Regarding men and women's participation in conflict resolution using ADR findings of a study carried out by Muigai (2017) in three provinces of Kenya indicate that most of these are male dominated, with women holding minimal positions. Muigia (2017) adds that in ADR, women continue to be discriminated even on matters that directly involve their rights. This is because ADRs are based on customary law which discriminates against women.

A comparative analysis derived from Canada, India, Nigeria, to Kenya, also indicate a strong gender omission as women's participation is quite low in comparison to men. The African Centre for the Constructive Resolution of Disputes (2015) concurs by noting that in almost all practices in Africa, the roles of women in ADR are obscure and indirect. This is derived from indigenous customs where women by design, were not represented in the eldership domain, who were purported to be "all conflicts resolvers". Women, however, were occasionally allowed to attend conciliatory forums if - and only if - their own cases were under discussion.

Such outright gender exclusion, continuously faced by women globally, has necessitated setting up and adoption of two instruments that champion for their protection and participation. These include the United Nations Security Council Resolution (UNSCR) 1325 on Women, Peace and Security commonly known as UNSCR 1325 and the Convention on the Elimination of All Forms of Discrimination against Women (CEDAW). These instruments are critical in moving the gender equality agenda forward in conflict and post conflict situations. UNSCR 1325 has aided a lot in broadening the scope of CEDAW's application by clarifying its relevance to both men and women in conflict and in peace. CEDAW on the other hand has provided concrete strategic guidance for actions to be taken on the broad commitments outlined in UNSCR 1325. Drawing from these two instruments has enabled advocates of human rights to maximize the impact of norms and standards for gender equality and equity in all conflict and post-conflict interventions. However, despite the ratification by Kenya of these instruments and the adoption of the Kenya 2010 constitution and other gender related policies and frameworks, gender equality is yet to yield expected fruit. Women in Kapsokwony continue to face discrimination because of multidimensional factors that this study identified and discussed.

\section{Objective}

The study objective was to discuss gender related factors that compromise men and women's participation in resolving community conflicts through ADR mechanisms in Kapsokwony. 


\section{Methodology}

The study was carried out in Kapsokwony sub-county, Bungoma County, in Kenya. Guided by the Peace Research theory, Social Exclusion theory and theory of Participation, it used a mixed research approach and adopted a descriptive survey research design. The sample size for the research was 384 respondents. The respondents were selected using both probability and non-probability sampling techniques, notably through random and purposive sampling methods. Emphasis was put on the fact that the respondents were part of Nyumba Kumi system. Data was collected using three instruments, namely, questionnaire, interviews, and Focus Group Discussion (FGD) guide. Data analysis was done using descriptive statistics, cross-tabulations, and frequencies. Qualitative data was analysed thematically.

\section{Literature}

Peace matters to everyone living in conflict regions. It concerns those who have seen their relatives killed, their houses demolished and the economy crash - those with memories and wounds that will stay with them forever (Carlman, 2012). The chances of lasting peace increase dramatically if not only the warring parties but also representatives from different groups in civil society, including women, sit at the negotiation table. The participation of women is therefore critical to the success of any peacebuilding process; women peacebuilders bring different perspectives and priorities to men, and their role in re-establishing the social fabric in the aftermath of conflict is vital. For peacebuilding initiatives to remain sustainable in the long-term, women must be included in every level of the process. This is not the case today; current formal peacebuilding processes often remain largely male-dominated, where women are simply as war victims (Peace Direct, 2020). This comes as no surprise to women activists who have advocated for decades that peace processes need to be inclusive to be sustainable (Carlman, 2012). Advocating for inclusivity comes because of women being exclude in peacebuilding processes because of different factors or barriers.

A comparative empirical research carried out by Muller and Justino (2012) on from the ground up Women's roles in local peacebuilding in Afghanistan, Liberia, Nepal, Pakistan and Sierra Leone, the authors identified six barriers to women participation to peacebuilding. These are (1) restrictive social norms and attitudes that reinforce traditional gender roles, making it difficult for women to participate safely and meaningfully in peacebuilding, (2) violence against women and girls, fueled by the long-term impact of conflict and militarization and (3) Poverty and economic inequality also inhibits women's involvement in peacebuilding activities. Other barriers include (4) inequality in access to education for women that results to low levels of women literacy, (5) the fact that women often de-value their role as peacebuilders, and despite their achievements, women do not necessarily recognize the important role they play in building peace and (6) barrier related to sustainability of support including limited and short-term funding and the challenges posed by a lack of national infrastructure and lack of access to remote communities (Muller \& Justino, 2012).

A similar study by O'Driscoll (2017) on Women's participation in peacebuilding and reconciliation in Iraq indicate that a number of obstacles to women's participation in the political sphere, including the security situation, cultural barriers, and the tribal/high ranking nature of negotiations.

In summary, the adoption of international instruments and national frameworks that foster gender equality is considered the result of women exclusion in peacebuilding process. Despite the progress so far achieved, a lot of literature report that women continue to face different obstacles to equality participating in peacebuilding.

\section{Findings}

It was therefore important to understand factors that continue to perpetuate unequal participation of men and women in resolution of community conflicts using ADR mechanisms. These factors included culture (i), religion (ii), education (iii) and gender perception (iv).

Table1. Factors that hinders equal participation of men and women in ADR processes

\begin{tabular}{|c|c|c|c|c|c|c|c|c|c|}
\hline & \multicolumn{2}{|c|}{$\begin{array}{c}\text { To a greater } \\
\text { extent }\end{array}$} & \multicolumn{2}{|c|}{ To a great extent } & \multicolumn{2}{|c|}{ To some extent } & \multicolumn{2}{|c|}{ I don't know } & No response \\
\hline & Men & Women & Men & Women & Men & Women & Men & Women & \\
\hline Culture & $\begin{array}{c}23 \\
(11 \%)\end{array}$ & $\begin{array}{c}39 \\
(19 \%)\end{array}$ & $\begin{array}{c}25 \\
(12 \%)\end{array}$ & $\begin{array}{c}45 \\
(22 \%)\end{array}$ & $\begin{array}{c}18 \\
(9 \%)\end{array}$ & $\begin{array}{c}43 \\
(21 \%)\end{array}$ & $\begin{array}{c}2 \\
(1 \%)\end{array}$ & $3(2 \%)$ & $7(3 \%)$ \\
\hline $\begin{array}{l}\text { Religious } \\
\text { beliefs }\end{array}$ & $\begin{array}{c}19 \\
(9 \%)\end{array}$ & $17(8 \%)$ & $\begin{array}{c}23 \\
(11 \%)\end{array}$ & $\begin{array}{c}49 \\
(24 \%)\end{array}$ & $\begin{array}{c}20 \\
(10 \%)\end{array}$ & $\begin{array}{c}62 \\
(30 \%)\end{array}$ & $\begin{array}{c}6 \\
(3 \%)\end{array}$ & $2(1 \%)$ & $7(4 \%)$ \\
\hline \multirow[t]{2}{*}{$\begin{array}{l}\text { Gender } \\
\text { perceptions }\end{array}$} & $\begin{array}{c}18 \\
(9 \%)\end{array}$ & $\begin{array}{c}20 \\
(10 \%)\end{array}$ & $19(9 \%)$ & $36(18 \%)$ & $\begin{array}{c}29 \\
(14 \%)\end{array}$ & $\begin{array}{c}67 \\
(33 \%)\end{array}$ & $\begin{array}{c}3 \\
(2 \%)\end{array}$ & $5(3 \%)$ & $7(3 \%)$ \\
\hline & \multicolumn{2}{|c|}{ Strongly agree } & \multicolumn{2}{|c|}{ Agree } & \multicolumn{2}{|c|}{ Disagree } & \multicolumn{2}{|c|}{$\begin{array}{l}\text { Strongly } \\
\text { disagree }\end{array}$} & No response \\
\hline $\begin{array}{l}\text { Education } \\
\text { level. }\end{array}$ & $\begin{array}{c}32 \\
(16 \%)\end{array}$ & $38(19 \%)$ & $31(15 \%)$ & $\begin{array}{c}80 \\
(39 \%)\end{array}$ & $\begin{array}{c}3 \\
(2 \%)\end{array}$ & $9(4 \%)$ & $\begin{array}{c}2 \\
(1 \%)\end{array}$ & $3(1 \%)$ & $(3 \%)$ \\
\hline
\end{tabular}




\subsection{Influence of Culture on Men and Women Participation in ADR Mechanisms}

Culture refers to a large and diverse set of mostly intangible aspects of social life. According to sociologists, culture consists of the values, beliefs, systems of language, communication, and practices that people share and that can be used to define them as a collective. Culture also includes the material objects that are common to that group or society (Cole, 2019).

In many African traditional societies, culture is important because it plays a significant and important role in the production of social order. The social order refers to the stability of society based on the collective agreement to rules and norms that allow us to cooperate, function as a society, and live together (ideally) in peace and harmony. For sociologists, there are both good and bad aspects of social order (Cole, 2019).

To maintain social order, the culture of Kapsokwony does not allow women to inherit land because they are meant to be taken into marriage and join a different family. According to culture, a woman is not supposed to speak before men and especially when her husband is around. According to the same culture women should oversee sharing food, eat late and aside and not to mingle with men in a community gathering. Furthermore, cultural practices also require a widow to be given out into a polygamous marriage and be disposed from his former husband land. These are just few of examples of cultural practices identified in Kapsokwony which are not different from other communities.

Thirty percent $(30 \%)$ were of the view that it was to a greater extent, $34 \%$ indicated that it was to a great extent while $30 \%$ indicated that culture contributed to unequal participation of men and women in ADR mechanisms to some extent. Two percent did not know and 3\% did not answer the question. The findings on Table 4.11 indicate that $94 \%$ of the respondent's concurred that culture compromised equal participation of men and women in ADR processes.

Table 2. Pearson correlation between culture and men and women participation in ADR

\begin{tabular}{|l|l|l|l|}
\hline \multicolumn{2}{|l|}{} & $\begin{array}{l}\text { Equal participation of } \\
\text { men and women }\end{array}$ & $\begin{array}{l}\text { Culture (traditional practices and customs) } \\
\text { continues to equal participation of men and } \\
\text { women in ADR processes }\end{array}$ \\
\hline $\begin{array}{l}\text { Equal participation of } \\
\text { men and women }\end{array}$ & Pearson Correlation & 1 & -.022 \\
\hline & Sig. (2-tailed) & & .757 \\
\hline $\begin{array}{l}\text { Culture (traditional } \\
\text { practices } \\
\text { customs) }\end{array}$ & Pearson Correlation & 199 & 193 \\
\hline
\end{tabular}

Results from Pearson Correlation between gender equality and traditional practices and customs show that there is $75 \%$ positive correlation $(\mathrm{r}=0.757)$ at level 0.01 without any significance $(-0.022)$ at level 0.05 between the two variables. This clearly shows that traditional practices and customs influence men and women participation in ADR processes in Kapsokwony. Quantitative data were supported by qualitative ones. While referring to culture

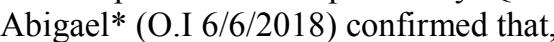

As a woman, I am not allowed to speak and give my opinion when elderly men are gathered and above all, if they are discussing issues affecting the community... My voice should be heard through my husband that is what our culture dictates...Any woman who tries to become vocal in the society is considered rebellious not only to her husband but also to the community. She will be silenced, and her husband will be directed to warn her. Besides, other women will not want to be associated with such a woman (Abigael* O.I 6/6/2018).

The women and men who attended the gender integrated FGD (8/6/2018), had this to say,

Culture remains strong in people minds; this is something that cannot be eradicated overnight. Off course in this community, it is not acceptable that a man stays at home and his wife goes around to dictate what should be done, such a man is considered weak and dominated by his wife. Men will not allow their wives to associate with such a woman. So, it is a matter of deep perception caused by culture in the society. A man is expected to represent his wife and family. This is what is culturally acceptable.

Mary* (O.I 6/6/2018) corroborated this by giving a similar opinion. She notes that,

... From the culture perspective, the welfare of a woman, especially a married one is dictated by her husband. The husband is the one to decide which welfare association his wife should attend, be it a conflict resolution process or not. Such decisions are final (Mary* O.I 6/6/2018).

As per the sentiments below, Moses (O.I 6/6/2018) argued however that there are some changes after the promulgation of the 2010 Kenyan Constitution, which gives women rights to inherit family property. He said that, We are starting to see some changes in terms of gender mainstreaming; especially since the adoption of the 2010 Constitution...the previous constitution and laws were also to blame for exclusion of women in the community exacerbated by social beliefs and norms that were strongly working against them. For example, many traditional practices, hindered women from inheriting any family property. When a woman is party to any land conflict, she is excluded from the process of resolving the dispute. The consequence is that we still 
have many unresolved family conflicts over land in the community (Moses (O.I 6/6/2018).

As far as resource control is concerned and in relation to culture, the views of many women in the FGD (8/6/2018) was that,

...There is no change as far as control over family resources is concerned. It is culturally known that the man is the one to has full control of family property, in fact they are put in the name of the husband even if the woman is the one who worked hard to obtain them. One would understand how strong the influence of male domination is in our community due to culture, which continues to perpetuate gender inequalities between men and women.

Richard*, the opinion leader (O.I 6/6/2018) as captured voiced the following,

...in many instances, women's views are not sought during decision-making processes while in others, the men are deemed to represent the interests of women. Culturally, it is clearly known that a woman should keep quiet when she is with her husband... And for a woman who keeps talking while the husband is quiet, something is wrong with her. She should rather keep quiet and wait for his opinion, because her opinion does not count. It is socially not acceptable that women have authority over men in our society (Richard* O.I 6/6/2018).

These qualitative data clearly indicate that from a cultural perspective, men continue to dominate the welfare, the voice and decision making of women in Kapsokwony. Women could not speak before elderly men, those who were married women, their voices were expressed through their husbands who decided to consider their opinions or not. Furthermore, a vocal woman was considered treacherous and was avoided by other women for the simple reason that she could negatively influence other women. According to men, their gender biased traditions would not change overnight. As such, women ought to know that they will remain under men's authority, whether they like it or not. In this regard the study found out that culture, which comprised traditional practices and customs, continue to greatly hinder gender equality in resolving conflicts using ADR mechanisms in Kapsokwony.

This finding confirmed the application of social exclusion theory in Kapsokwony. This theory states in part that the social, political, economic, and cultural disempowerment and alienation of women hinder the ability to participate effectively in productive community activities such as conflict resolution. This means that among the factors that are contributing to social exclusion of women in Kapsokwony, traditional practices and customs were found to play a crucial role. These findings are like those of Colombia during the Peace Process. Rural women were not included in the peace process and the agreement did not recognize their rights, instead they were just mentioned as only beneficiaries of public programmes and limiting them to their role within the family unit (Oxfam GB, 2017). The situation in Kapsokwony is not different since women were limited to their role within the family unit. One would understand that women exclusion is global problem that needs to be addressed using long-term measures. In our view this is largely because of the patriarchal organization of the Kapsokwony society which privileges men in this regard to decision making while disadvantaging women.

From these discussions, the study clearly concludes that culture remains a strong factor that continues to negatively affect equal participation of men and women in ADR processes in Kapsokwony.

\subsection{Religious Beliefs and Gender Participation in ADR}

A religion can be understood as a unified system of beliefs and practices relative to sacred things, that is to say, things set apart and forbidden - beliefs and practices which unite into one single moral community called a Church, all those who adhere to them." (b) [Religion is] "the self-validation of a society by means of myth and ritual.

Christian and Islam religions for example do not allowed women to lead any service within the congregation. In particular, the bible scriptures do not allow women to preach or to take authority over men. Some other scriptures order them to keep quiet in the church and if they have any question to ask their husband at home. While other do not allow a woman to be a pastor to the extent that the church leadership would be exclusively made of men. So, when talking of religion, references are made about these considerations which contribute to social inequalities. Ninety three percent $(93 \%)$ of the respondents believed religious beliefs affected participation of men and women in the community in one way or another. The remaining $7 \%$ were either non-committal or unaware.

Table 3. Pearson correlation between men and women participation and religion beliefs

\begin{tabular}{|c|c|}
\hline & $\begin{array}{l}\text { Religion beliefs } \mid \text { Men and women } \\
\text { continue to prevent participate in conflict } \\
\text { equal participation of } r \text { resolution equally in } \\
\text { men and women } \\
\text { Kapsokwony. }\end{array}$ \\
\hline Religion beliefs continue to prevent Pearson Correlation & .128 \\
\hline equal participation of men and Sig. (2-tailed) & .077 \\
\hline Women & 198 \\
\hline Men and women participate inPearson Correlation & .128 \\
\hline conflict resolution equally in Sig. (2-tailed) & .077 \\
\hline Kapsokwony. & 193 \\
\hline
\end{tabular}


Pearson's correlation between religious beliefs and men and women participation in resolution of community conflicts showed a positive correlation $(\mathrm{r}=0.0128)$ at level of 0.01 but without significance $(0.077)$ at 0.05 . This meant that in Kapsokwony, religious beliefs constituted another factor that adversely affected equal participation of men and women in community conflicts resolution using ADR mechanisms. This is a confirmation of the descriptive analysis whereby the overwhelming majority cited religious beliefs. Their opinions are hereby presented here:

Andrew* (O.I 6/6/2018) explained that,

...religion is being used by men as a tool to exclude women from participating in ADR so that they can remain oppressed by men. Being a community where most people are Christians, bible verses regarding women submission to their husbands is in many cases are blindly applied (Andrew, O.I 6/6/2018).

Views of participants in the women FGD (8/6/2018) were no different. They retorted that,

Christians are thought to obey the word of God and the society knows that wives are required to submit to their husbands. This kind of perception is being used from different angles to ensure that women remain unequal to men excluding them from important issues including ADRs.

Views of participants in men FGD (8/6/2018) were not different. According to them, they observed that,

Both in Christianity and in Islam, a woman is required to fully submit to her husband and if she is a faithful believer, she must obey, there is no short cut. It is not normal that a woman stands to speak yet the husband is quiet. From the religious perspective, the husband is the head, and this should apply not just in church but also in social life.

Mary* (O.I 6/6/2019) rather provided an elaborated explanation regarding religion as factor that hinders equal participation of men and women in ADR processes. According to her,

...It is not about religion per se that does not allow us to participate in ADR process. It is rather wrong interpretation of what religion says. When the bible says that we should submit to our husband, it does not mean that we should not participate in ADR processes. The real issue is rather men who really do not want us (women) to fully participate with them in the process. Besides, when the bible says that women should ask their husbands questions at home, it does not apply to ADR processes, it is rather in church and ADR process is not a church function (Mary*, O.I 6/6/2019).

The analysis of both quantitative and qualitative data confirms that religious beliefs continue to be an impediment to gender equality in resolution of community conflicts. While some participants confirmed the existence of religious scriptures that require full submission of women to their husbands, others however were of the view that it was a wrong interpretation of the same religious scriptures that men have taken advantage of so as not allow women to fully participate in resolution of conflicts through ADR mechanisms. In other words, there was no relationship between the scriptures that impose full submission of women to their husbands and not allowing them to fully participate in ADR processes.

In other countries, interpretation of religious scriptures continues to contribute to a large extent to the social exclusion of women from many spheres of life including conflict resolution. In Saudi Arabia for instance, gender inequality is rooted in religious beliefs that legitimize women's traditional absence and silence in public life. This comes from the normalization of gender differences in the curriculum content at all school ages for both boys and girls (Rajkhan, 2014).

Despite strides made towards gender equality, religious beliefs greatly influence unequal participation of men and women in resolution of conflict through ADR mechanisms in Kapsokwony.

\subsection{Influence of Education on Participation of Men and Women in ADR Processes}

When asked to indicate whether education influenced women participation in decision-making processes in ADR mechanisms, $89 \%$ of the respondents either strongly or simply replied in the affirmative; with the remaining 8 percent disagreeing and another $3 \%$ indicating non-committal.

Table 4. Pearson correlation between Education and men and women participation

\begin{tabular}{|c|c|c|}
\hline & $\begin{array}{l}\text { Education contributes } \\
\text { to equal participation } \\
\text { of men and women }\end{array}$ & $\begin{array}{l}\text { Men and women } \\
\text { participate in conflict } \\
\text { resolution equally in } \\
\text { Kapsokwony. }\end{array}$ \\
\hline \multirow{3}{*}{\begin{tabular}{|l|l|l|l|l|l|l|l}
$\begin{array}{l}\text { Education contributes to equal } \\
\text { participation of men and women. }\end{array}$ & $\frac{\text { Sig. (2-tailed) }}{\mathrm{N}}$ \\
\end{tabular}} & 1 & .039 \\
\hline & & .0593 \\
\hline & 198 & 194 \\
\hline \multirow{3}{*}{$\begin{array}{l}\text { Men and women participate in } \\
\begin{array}{l}\text { Penflict resolution } \\
\text { conson Correlation } \\
\text { Kapsokwony. }\end{array}\end{array}$} & .039 & 1 \\
\hline & .0593 & \\
\hline & 194 & 198 \\
\hline
\end{tabular}

Furthermore, a Pearson correlation between education level and men and women participation in ADR processes in Kapsokwony showed a positive correlation between the two variables $(r=0.039)$ at level 0.01 without 
any significance $(0.593)$ at a level 0.05 . This meant that education level of women was considered important for women participation in resolution of community conflict using ADR mechanisms as well as having equal influence on decision making in the same process. Therefore, an educated woman would be easily be allowed to attend meetings that resolve community conflict and have equal influence in decision making as men compared to a woman who is not educated. Descriptive and inferential analysis confirmed the importance of education as key to participating in resolution of community conflicts in Kapsokwony.

On the other hand, data from qualitative data was not different, it provided clarification on the aspects of education.

A respondent; Jane* (O.I 6/6/2018) noted that,

...it is difficult to involve someone, either a woman or a man, who has not gone to school to be part of the team in charge of community conflict considering the complexities involved. Today we have women who are involved/in charge of addressing GBV in the community after attending different trainings on the same through different NGOs. We also have few women who are part of the council of elders and they actively participated in the negotiation of Mabanga Peace Agreement, it is due to their level of awareness and formal education (Jane* O.I 6/6/2018).

Observations based on the female (FGD 8/6/2018) indicated that,

...there are very few women who are educated in the County and community. However, these are respected and allowed to make decisions. Besides, they have big positions in the County and Sub County because of their education. When you are educated men might fear, respect, and honour you. We agree that education is significant in our community.

Conjestina* (O.I 6/6/2018), the area chief of Elgon location held the same opinion. She observed that,

Education is considered when interviewing and selecting women at leadership levels. An educated woman will be much respected. People will honour her. Besides when talking of education, it is not necessarily about going to school. Other forms of education, such as programs that NGOs bring in the community such para legal programs, programs on conflict resolution, community awareness, gender empowerment programs are also of added value for someone to be considered (Conjestina* O.I 6/6/2018).

According to Peter* (O.I 6/6/2018), a respondent, when a woman is educated and respects herself, people look up to her differently.

Qualitative data confirmed the importance of education as a key element for respect and power in Kapsokwony. It also indicated that education of women was key in empowering and recognizing the efforts in participation of ADR mechanisms. Moreover, some level of education be it formal or informal granted some women power and authority to be location and sub-location chiefs and assistant chief as well as working in the county government.

The study also established that education was understood not just in the sense of formal whereby which enabled some women to be given powerful positions at sub-locational, locational and sub-county level but also informal which involved awareness creation, assertiveness and trainings which were offered outside the formal framework and allowed women to gain confidence and stand for their rights and their views in the community. Indeed, when a woman is educated, she acquired respect and honour from the community members that contributed to community acceptance and trust of her participation in resolution of community conflict using ADR mechanisms. Education therefore boosted the women level of acceptance and trust contrary to a woman who never had any level of formal or informal education. This view was supported by the fact that some women who occupied the positions of chief and assistant chiefs had been granted such positions in consideration of their requirements including level of formal and informal education.

Consequently, they were fully in charge of convening, leading, and making decision on conflicts brought before them as explained under second objective of the study. Education therefore comes in as equalizer between men and women as far as equal participation in resolution of conflicts using ADR mechanisms is concerned.

Baker (2011) confirms the same when he notes that the low levels of educational, especially among women, represent a very serious constraint on development in most of the Sub - Saharan countries, Kenya included. At the individual level, for example, education is perceived to be the ultimate liberator, which empowers a person to make personal and social choices. The World Bank argues that education is also perceived to be the ultimate equalizer, particularly in promoting greater equity for women.

The study therefore concludes that lack of some level of literacy be it formal or informal constituted a factor that impeded equal participation of men and women in resolution of community conflict through ADR besides culture and religion beliefs.

\subsection{The Role of Gender Perceptions in Hindering Men and Women's Equal Participation in ADR Process}

Gender perception is hereby understood as women's and men's perceptions that some tasks and responsibilities can only be done either by women or men, that man should not be seen involved in such tasks or responsibility that are recognized to be performed only by women and vice versa. The study therefore sought to know whether 
women and men considered the task of resolving community conflicts as a task to be performed only by men hence contributing to unequal participation of men and women in resolution of community conflicts through ADR mechanisms.

When asked to indicate whether gender perceptions continue to perpetuate unequal participation of men and women in resolution of conflicts using ADR mechanisms, a simple majority of respondents, $47 \%$ ( 27 males and 69 females) indicated that to some extent gender perceptions did contribute to gender inequality. A few of the respondents $56(27 \%)$ (19 males and 36 females) believed that to a great extent, while a small number, $38(18 \%)$ respondents (18 males and 20 females), indicated to a greater extent. The analysis of these data infers that gender perceptions contribute to unequal participation of men and women in ADR process to a lower extent. Participants to FGDs provided some elaboration on the same.

The view of participants in women FGD (8/6/2018) was that,

...These long-standing traditional practices have made women believe that they should not be part of many community processes especially when they have to do with men. Those who try to dare the odds are even challenged by fellow women. One would even find that women do consider their fellows women outcast for the simple reason that they are standing to compete with men on equal footing for leadership positions for example; you will find that even where only women are required to fill in a position, nobody will come up, only for fear to be branded as a vocal and bad women in the society.

Furthermore, Hannah* (KI, 6/6/2018), a respondent explained that,

...you will find that most of us believe that resolving a conflict is a responsibility of men and this is the reason why you will find that many women would not be ready to go and sit down with those elder men to discuss about conflicts unless you are personally affected as a victim or required to attend. Again, men would not accept to have their wives attending such a gathering, they would instruct them to stay at home and take care of the household. Women also prefer doing their own business than going to sit with elderly men to resolve community conflicts. So, it is a matter of perception that people have accumulated for years because of longstanding tradition and culture (Hannah* KI, 6/6/2018).

Geoffrey* was of the same view with Hannah. He explained that,

Not only women, even men consider resolving community conflicts as task that belongs to men only, women have to leave it to men and perform their task such as taking care of households, milking cows, cultivating and taking care of children (Geoffrey*, KI 6/6/2018).

\section{Discussions}

The analysis of these qualitative observations revealed that long standing tradition and culture among the community of Kapsokwony which had been accumulated over years contributed to gender perceptions about the roles that men and women played. Gender perceptions seemed to be internalized among the community to the extent that both women and men knew their boundaries in terms of what a woman/man should and should not do. In this case, resolution of conflict was perceived to be men's responsibility while household chores like, milking cows, cultivating, and taking care of children were considered women responsibility in Kapsokwony. In fact, women preferred doing their chores than sitting down with elderly men to resolve community conflicts.

The study noted that gender perceptions in Kapsokwony was a result of division of roles which had been strengthened by application of long standing cultural and tradition practices. The study therefore concludes that gender perceptions also contributed to unequal participation of women and men in resolution of community conflicts through ADR processes besides culture, level of women literacy and interpretation of religious beliefs.

The study established that a woman with some level of literacy is respected and allowed to participate on equal footing with men to discuss and even resolve community conflicts (case of women chiefs). Finally, the study also established that gender perceptions continue to make people divide roles and responsibilities according to their gender; as a result of this, conflict resolution is considered as a role and responsibility of men rather than of women in Kapsokwony as confirmed by both quantitative and qualitative data analysis.

These factors continue to perpetuate social exclusion of women in resolution of community conflicts through ADR, confirming therefore the application socio-exclusion theory. In other words, there is a multidimension of socio-religious (culture and religion interpretation) and individual factors (level of literacy and gender perception) that continue to sustain socio-exclusion of women and contribute to their passive participation in resolution of community conflicts in Kapsokwony.

\section{Conclusions and Recommendations}

The analysis and discussions on gender related factors that compromised equal participation of men and women in ADR process established that there was a combination of factors that continue to perpetuate unequal participation of men and women in ADR process. These are culture, understood as existing traditional practices and customs that continue to support women exclusion, religious beliefs that a woman should be under a man authority, obeying him in everything including even when he does not want her to participate in any gathering that 
would resolve any community conflict or to play any role. Other factors include level of women literacy whereby a woman with some level of literacy is favoured to participate in ADR processes than the one with low level of literacy, literacy understood in terms of both formal and informal education.

To work towards equal participation of men and women in ADR processes, the study proposes the following recommendations:

1) The Kenya constitution 2010 has recognized the relevance of ADR as conflict resolution mechanisms at different levels. Recognition is not enough. The study therefore recommends that the National and County governments establish viable ADR formation structures which are gender inclusive as well as guidelines or standards to be followed in each ADR process.

2) The study also recommends that parties who opt to resolve their disputes through ADR ought to have access to legal advice to prevent negative effects of power imbalance.

3) To contribute to equal participation of men and women in resolution of community conflicts, the study recommends that Bungoma County Gender Technical Working Group works in partnership with the civil society to implement a comprehensive program on civic education. This program should aim to reduce the negative impacts of culture on women participation in ADR mechanisms and contribute to raising awareness of both women and men on the importance of gender inclusivity in ADR mechanisms.

\section{References}

Baker, B. (2011). World Development: An Essential Text. London: Cengage.

Carlman, A. (2012). Equal Power - Lasting Peace Obstacles for women's participation in peace processes. Johanneshov: Kvinna till Kvinna .

Cole, N. (2019, August 2). So What Is Culture, Exactly? Retrieved from Science, Tech and Math: https://www.thoughtco.com/culture-definition-4135409

Muigai, K. (2017). Institutionalising Traditional Dispute Resolution Mechanisms and other Community Justice Systems. Nairobi: Published online.

Muller, C. \& Justino, P. (2012). From the ground up Women's roles in local peacebuilding in Afghanistan, Liberia, Nepal, Pakistan and Sierra Leone. ActionAid, Womankind and IDS.

O'Driscoll, D. (2017). Women's particiption in peacebuilding nd reconciliation in Iraq. Manchester: Helpdesk .

Oxfam GB. (2017). Supporting rural women to drive peacebuilding processes in Colombia. Oxford: OXFAM GB.

Peace Direct. (2020, August 28). Women, Peace and Security. Retrieved from Peace Insight: https://www.peaceinsight.org/themes/women-peace-security/

Rajkhan, S. (2014). Women in Saudi Arabia, Status, Rights, and Limitations. University of Washington Bothell .

The African Centre for the Constructive Resolution of Disputes (ACCORD). (2015). Alternative disputes resolution and peace studies in Africa: lessons, prospects and challenges. the Fourth International Africa Peace and Conflict Resolution Conference (pp. 1-37). Johannesburg: ACCORD. 